\title{
Pengembangan Ekonomi Melalui Sektor Pariwisata
}

\author{
Sukarno Wibowo*1, Odang Rusmana², Zuhelfa ${ }^{3}$, Syaeful Muslim ${ }^{4}$ \\ Sekolah Tinggi Pariwisata Bandung, Indonesia ${ }^{1,2,3,4}$ \\ Email: sukarnowibowo@stp-bandung.ac.id
}

\begin{abstract}
Tourism sector is one of the activities that have a strategic role in support international economic developmentin the era of globalization. Influence the development of the tourism industy for the development of the region in the vicinity of the attractions, so as to act as leading industries, the sectors that can boost the economy. The existence o fthe tourism sector will be able to create jobs that will boost the income of the people in the tourist areas When associated with economic developrnent with a balanced growth, tourism can be expected to hold a decisive roleandcan be used a cacatalyst to develop ot her sectors of development. Meanwhile, the economic impact pariwista development can have positive or negative. Its positive impactis(1) create jobs; (2) increasing opportunities, (3) increase the income of the people in the tourist area around. While the negative impact on the environment tis the natural, built environment and cultural environment.
\end{abstract}

Keywords: Tourism, Development and Economic

Abstrak

Sektor pariwisata adalah salah satu kegiatan yang memiliki peran strategis dalam mendukung pembangunan ekonomi internasional di era globalisasi. Mempengaruhi pengembangan industri pariwisata untuk pengembangan kawasan di sekitar objek wisata, sehingga dapat bertindak sebagai industri terkemuka, sektor-sektor yang dapat meningkatkan perekonomian. Keberadaan sektor pariwisata akan dapat menciptakan lapangan kerja yang akan meningkatkan pendapatan masyarakat di kawasan wisata. Ketika dikaitkan dengan perkembangan ekonomi dengan pertumbuhan yang seimbang, pariwisata dapat diharapkan untuk memegang peran yang menentukan dan dapat digunakan sebagai katalis untuk mengembangkan sektor pembangunannya. Sementara itu, dampak ekonomi perkembangan pariwista bisa positif atau negatif. Dampak positifnya adalah (1) menciptakan lapangan kerja; (2) meningkatkan peluang, (3) meningkatkan pendapatan masyarakat di kawasan wisata sekitar. Sedangkan dampak negatifnya terhadap lingkungan adalah lingkungan alam, lingkungan terbangun dan budaya.

Kata kunci: Pariwisata, Pengembangan dan Ekonomi

\section{A. PENDAHULUAN}

Pada perkembangannya, pariwisata dewasa ini memiliki peranan yang strategis dalam pembangunan ekonomi diberbagai negara. Banyak negara yang terus menggarap potensi pariwisata dengan serius dan menjadikan pariwisatasebagai sektor unggulan di dalam perolehan devisa, penciptaan Iapanganpekerjaan maupun pengentasan kemiskinan. Adapun pariwisata dengan berbagai aspek positifnya, dipandang sebagai passport to development, new kind of sugar, tool for regional development, invisible export, non-polluting industry dan sebagainya (Pitana, 2002:13). Namun demikian, tidak jarangpariwisata yang hanya diperlakukan sebagai sebuah industri biasa, hal initentunya berimplikasi pada pengembangan pendidikan pariwisata yang menekankan pembelajaran pada aspek technical know-how, sementarasisi know-what dan know-why masih relative tertinggal dan kurang berkembang. Pengembangan pariwisata di Indonesia pada realitasnya terus berkembang dan merupakan salah satu faktor penting dalam menopang perekonomian negara. Perkembangan ini dikarenakan pariwisata Indonesia memiliki potcnsi pariwisata yang begitu besar sehingga dapat menarik minat investor untuk menanamkan modalnya (berinvestasi) dan mengembangkan potensi pariwisata yang telah

\footnotetext{
* Corresponding author 
terscdia. Pada sisi lain pariwisata juga dapat berfungsi untuk membawa nama atau citra bangsa Indonesia agar dikenal didunia Internasioanal.Sebagai salah satu sektor pembangunan yang dapat memacu pertumbuhan ekonomi suatu wilayah, pariwisata dianggap sebagai suatu aset yang strategis untukmendorong pembangunan pada wiiayah-wilayah tertentu yang mempunyai potensi objek wisata (Soemardjan, 1992: 58).Dengan adanya perkembangan industry pariwisata di suatu wilayah, ants urbanisasi ke kota-kotabesar tentunya dapat lebih ditekan.

Keberadaan sector pariwisata tersebut seharusnya memperoleh dukungan dari semua pihak seperti pemerintah sebagai pengelola, masyarakat yang beradadi lokasi objek wisata serta partisipasi pihak swasta sebagai pengembang dan pengelola pariwisata.Selain peran yang dimilikinya, pariwisata juga merupakan suatu sektor yang tidak jauhberbeda dengan sektor ekonomi yang lain yaitu dalam proses perkembangannya juga mempunyai dampak atau pengaruh dibidang social dan ekonomi masyarakat. Adapun pengaruh yang ditimbulkan tersebut dapat berupa pengaruh positif maupun negative terhadap kehidupan masyarakat setempat. Untuk mencegah perubahaan itu menuju ke arah negatif maka diperlukan perencanaan yangmencakup berbagai aspek khusunya sosial dan ekonomi, sehingga sedapat mungkin masyarakat setempat ikut terlibatdi dalam perencanaan dan pengembangan pariwisata.

Proses pembangunan dan pengembangan suatu wilayah di Indonesia pada prinsipnya dapat ditunjang oleh potensi wisata yang dimilikinya. Berdasarkan data statistik tercatat bahwa sektor pariwisata memberikan kontribusi yang cukup besar terhadap perekonomian nasional. Adapun jumlah kunjungan wisatawan mancanegara (wisman) ke Indonesia pada Desember 2013 mencapai 860,7 ribu kunjungan atau naik 12,22 persen dibandingkan jumlah kunjungan wisman Desember 2012, yang sebanyak 767,0 ribu kunjungan. Begitu pula, jika dibandingkan dengan November 2013, jumlah kunjungan wisman Desember 2013 naik sebesar 6,59 persen. (BPS, 2014: 1). Dengan potensi wisata yang dimiliki masih memungkinkan peluang peningkatan penerimaan negara dari sektor pariwisata.

Meskipun demikian, sektor pariwisata sangat rentan terhadap faktor-faktor lingkungan alam, keamanan, dan aspek global lainnya. Sebagai contoh isue terorisme, kerusakan alam dan krisis ekonomi dunia yang telah terjadi cukup mengganggu pengembangan ekonomi pariwisata di Indonesia. Selain itu masih terbatasnya dukungan sarana dan prasarana dalam menunjang kegiatan pariwisata telah mengakibatkan tidak maksimalnya pengembangan ekonomi pariwisata di Indonesia. Permasalahan terjadi juga pada pola pengelolaan kawasan pariwisata yang tidak menyeluruh (comprehensive), kenyataanya initelah menimbulkan dampak negatif yang mengakibatkan menurunnya daya tarik obyek wisata, misalnya timbulnya kerusakan lingkungan, meningkatnya urbanisasi ke lokasi obyek wisata yang telah meningkatkan permasalahan sosial antara lain meningkatnya tindak kejahatan dan kegiatan sektor informal yang tidak terkendali.

Berdasarkan uraian di atas, permasalahan dalam tulisan ini dapat dirumuskan sebagai berikut:

1. Bagaimana pengembangan ekonomi melalui sektor kepariwisataan?

2. Sejauhmana dampak pengembangan pariwisata bagi ekonomi?

\section{B. KAJIAN PUSTAKA}

\section{Pengertian Pariwisata}

Secara umum pariwisata merupakan suatu perjalanan yang dilakukan seseorang untuk sementara waktu yang diselenggarakan dari suatu tempat ke tempat yang lain dengan meninggalkan tempat semula dan dengan suatu perencanaan atau bukan maksud untuk mencari nafkah di 
tempat yang dikunjunginya, tetapi semata-mata untuk menikmati kegiatan pertamasyaan atau rekreasi untuk memenuhi keinginan yang beraneka ragam

Pariwisata merupakan istilah yang diberikan apabila seseorang wisatawan melakukan perjalanan itu sendiri, atau dengan kata lain aktivitas dan kejadian yang teijadi ketikaseseorang pengunjung melakukan perjalanan. Pariwisatasecara singkat dapat dirumuskan sebagai kegiatan dalam masyarakat yang berhubungan dengan wisatawan (Soekadijo, 2000: 2).

Menurut Wahab (1989:55) pariwisata merupakan suatu aktivitas manusia yang dilakukan secara sadar yang mendapat pelayanan secara bergantian diantara orang-orang dalam suatu negara itu sendiri atau di luar negeri (mcliputi pendiaman orang-orang dari daerah lain) untuk mencari kepuasan yang beraneka ragam dan berbeda dengan apa yang dialaminya dimana ia memperoleh pekerjaan tetap.

Sedangkan menurut Sihite dalam Marpaung (2000:46-47) menjelaskan pariwisata adalah suatu perjalanan yang dilakukan orang untuk sementara waktu, yang diselenggarakan dari suatu tempat ke tempat lain meninggalkan tempatnya semula, dengan suatu perencanaan dan dengan maksud bukan untuk berusaha atau mencari nafkah di tempat yang dikunjungi, tetapi semata-mata untuk menikmati kegiatan pertamsyaan dan rekreasi atau untuk memenuhi keinginan yang beraneka ragam. Sementara itu, Spillane (1989:20) mengemukakan bahwa pariwisata adalah kegiatan melakukan perjalanan dengan tujuan mendapatkan kenikmatan, mencari kepuasan, mengetahui sesuatu, memperbaiki kesehatan, menikmati olahraga atau istirahat, menunaikan tugas, berziarah dan lain-lain.Pariwisata bukan saja sebagai sumber devisa, tetapi juga merupakan faktordalam menentukan lokasi industri dalam perkembangan daerah-daerah yang miskinsumber-sumber alam sehingga perkembangan pariwisata adalah salah satu cara untukmemajukan ekonomi di daerah-daerah yang kurang berkembang tcrsebut sebagaiakibat kurangnya sumber-sumber alam (Yoeti, 1996:234).Pariwisata merupakan bagian yang tidak terpisahkan dari kehidupan manusiaterutama menyangkut kegiatan sosial dan ekonomi. Diawali dari kegiatan yang semulahanya dinikmati oleh segelintir orang-orang,kini telah menjadi bagian dari hak azasi manusia. Hal ini teijadi tidak hanya di negaramaju tetapi mulai dirasakan pula di negara berkembang. Indonesia sebagai Negarayang sedang berkembang dalam tahap pembangunannya, berusaha membangun industri pariwisata sebagai salah satu cara untuk mencapai neraca perdagangan luarnegeri yang berimbang. Melalui industry ini diharapkan pemasukan devisa dapat bertambah (Pendit, 2002:32). Sebagaimana diketahui bahwa sector pariwisata di Indonesia masih menduduki peranan yang sangat penting dalam menunjangpembangunan nasional sekaligus merupakan salah satu factor yang sangat strategis untuk meningkatkan pendapatan masyarakat dan devisa negara.

\section{Pengembangan Ekonomi Pariwisata}

Pengembangan pariwisata merupakan suatu proses yang dinamis dan berkelanjutan menuju ketataran nilai yang lebih tinggi dengan cara melakukanpenyesuaian dan koreksi berdasar pada basil monitoring dan evaluasi serta umpanbalik implementasi rencana sebelumnya yang merupakan dasar kebijaksanaan danmerupakan misi yang harus dikeinbangkan. Perencanaan dan engembanganpariwisata bukanlah sistem yang dapat berdiri sendiri, melainkan berkaitan dengan sistemperencanaan pembangunan yang lain secara inter sektoral dan inter regional. Pengembangan kepariwisataan saat ini tidak hanya untuk menambah devisa negara maupun pendapatan pemerintah daerah, tetapi juga diharapkan dapat memperluas kesempatan berusaha disamping memberikan lapangan pekerjaan baru untuk mengurangi pengangguran di daerah. Pariwisata dapat menaikkan taraf hidup masyarakat yang tinggal di kawasan tujuan wisata tersebut melalui keuntungan secara ekonomi. Dengan mengembangkan fasilitas yang mendukung dan menyediakan fasilitas rekreasi, wisatawan dan penduduk setempat saling diuntungkan. 
Pengembangan daerah wisata hendaknya memperlihatkan keanekaragaman budaya, sejarah dan tingkat ekonomi dari daerah tujuan wisata. Pengaruh yang ditimbulkan oleh pariwisata terhadap ekonomiada dua ciri, pertama produk pariwisata tidak dapat disimpan, kedua permintaanya sangat tergantung pada musim, berarti pada bulan tertentu ada aktivitas yang tinggi,sementara pada bulan-bulan yang lain hanya ada sedikit kegiatan (musim sepi wisatawan).

\section{METODE PENELITIAN}

Pendekatan yang digunakan dalam penelitian ini adalah deskriptif analisis dengan pendekatan kualitatif. Pendekatan kualitatif digunakan karena perumusan gejala-gejala, informasi- informasi atau keterangan-keterangan mengenai pengembangan ekonomi melalui sektor pariwisata. Dengan demikian dalam penelitian ini, peneliti ingin menggambarkan suatu realitas mengenai pengembangan ekonomi pariwisata. maka jenis penelitian yang paling tepat adalah jenis kualitatif dengan m etode deskriptif analisis, dim ana data lebih berbentuk kata-kata. Adapun teknik pengumpulan data melalui observasi, wawancara dan dokumentasi, sedangkan teknik analisis data dilakukan dengan cara pengumpulan data, reduksi data, penyajian data dan verifikasi/kesimpulan.

\section{HASIL DAN ANALISIS}

Sektor pariwisata di Indonesia merupakan salah satu sektor penting terhadap perekonomian negara. Pada tahun 2013, sektor pariwisata memiliki kontribusi yang besar bagi devisa negara, dimana penerimaan devisa pariwisata pada tahun 2013 diperkirakan mencapai USS10,1 miliar atau naik 10,99 persen dibanding penerimaan devisa tahun 2012 yang sebesar US\$9,I miliar (BPS, 2014: 1). Data tersebut memperlihatkan bahwa pariwisata memiliki peranan dalam menyumbang devisa negara. Realitas ini tentunya inemerlukan pengembangan pada kawasan pariwisata di Indonesia dalam meningkatkan devisa bagi negara.

Perkembangan suatu kawasan wisata tidak terlepas dari usaha-usaha yang di lakukan melalui kerjasama para stakeholder kepariwisataan, masyarakat dan pemerintah. Konsep ini memperlihatkan bahwa pengembangan pariwisata merupakan segala kegiatan dan usaha yang terkordinasi untuk menarik wisatawan sekaligus menyediakan sarana prasarana,barang dan jasa, fasilitas yang diperlukan guna melayani kebutuhan wisatawan.

Selanjutnya dalam meningkatkan potensi pariwisata agar memiliki nilai ekonomi, perlu diperhatikan dalam pengembangan suatu daya tarik wisata yang potensial harus dilakukan penelitian, inventarisasi dan evaluasi sebelum fasilitas wisata di kembangkan.

Hal ini penting agar perkembangan daya tank wisata yang ada dapat sesuai dengan keinginan pasar potensial dan untuk menentukan pengembangan yang tepat dan sesuai sasaran.

Hasil penelitian menunjukan bahwa terdapat tiga aspek yang dapat menentukan berhasilnya pengembangan pariwisata sebagai suatu industri, ketiga faktor tersebut diantaranya: tersedianya objek atraksi wisata yang baik, terpenuhinya fasilitas aksesisibilitas dan pariwisata yang bemilai untuk

dikunjungi. Selain itu dalam pengembangan kepariwisataan perlu diperhatikan kualitas lingkungan agar pengembangan kepariwisataan tidak menisak lingkungan dimana industry pariwisata kelangsungan hidupnya sangat ditentukan oleh baik buruknya lingkungan. Tanpa lingkungan yang baik tak mungkin pariwisata berkembang. Oleh karena itu pengembangan pariwisata haruslah memperhatikan terjaganya mutu lingkungan, sebab dalam industri pariwisata lingkungan itulah yang sebenarnya dijual. Pengembangan pariwisata disuatu wilayah ditentukan oleh tiga faktor yaitu: tersedia objek dan atraksi pariwisata, aksesibilitas dan fasilitas amenitas. Dalam membangun ketiga faktor tersebut harus diperhatikan terjaganya mutu lingkungan. 


\section{Pengembangan Ekonomi Melalui Sektor Kepariwisataan}

Pariwisata merupakan bagian dari sektor industri di Indonesia yang memiliki prospek, potensi serta peluang yang sangat besar untuk dikembangkan. Peluang tersebut tentunya didukung oleh kondisikondisi alamiah sepert lokasi dan keadaan geografis, lapisan tanah yang subur dan panoramis, serta berbagai flora dan fauna. Tujuan dari pengembangan sector pariwisata ialah sebagai upaua dalam meningkatkan kualitas hidup dan kesejahteraan serta dapat memberikan manfaat terhadap pemenuhan kebutuhan masyarakat. Dengan mengembangan sektor pariwisata ini dimungkinkan dapat memberikan kontribusi terhadap perbaikan kesejahteraan masyarakat.

Pada pelaksanaan pembangunan perekonomian dengan suatu pertumbuhan yang berimbang, kepariwisataan dapat diharapkan memegang peranan yang menentukan dan dapat dijadikan sebagai katalisator untuk mengembangkan pembangunan sektor-sektor lain secara bertahap. Adapun hasil penelitian menunjukan bahwa kebijakan pemerintah pada sektor pariwisata ada yang memberikan dampak langsung dan ada pula yang memberikan dampak tidak langsung. Selain dari hal diatas ada kemungkinan suatu kebijakan ekonomi pemerintah memberikan dampak langsung pada sektor lain tetapi dapat memberikan dampak tidak langsung bagi sektor pariwisata.Tujuan pokok dari kebijakan ekonomi pemerintah terhadap pariwisata adalah untuk memaksimalkan kontribusi pariwisata terhadap ekonomi nasional.Tujuan kontribusi ini diantaranya:

(a) Peningkatan kontribusi pariwisata dalamneraca pembayaran

(b) Memperluas kuantitas lapangan kerja

(c) Meningkatan dan mendistnbusian pendapatan masyarakat

(d) Kontribusi terhadappeningkatan kesejahteraan sosial

(e) Optimalisasi peluang pendapatan fiskal

Pada pengembangan pariwisata tentunya membutuhkan pengembangan yang berencana secara menyeluruh, sehingga' dapat diperoleh manfaat yang maksimal bagi masyarakat baik dari segi ekonomi, social dan cultural. Perencanaan tersebut harus mengintegrasikan pariwisata kedalam suatu program pembangunan ekonomi, fisik, dan sosial dari suatu negara. Di samping itu, rencana tersebut harus mampu memberikan kerangka kerja kebijakan pemerintandalam mendorong dan mengendalikan pengembangan pariwisata. Peranan pemerintah dalam mengembangkan pariwisata dalam garis besarnya adalah menyediakan infrastuktur, memperluas berbagai bentuk fasilitas, kegiatan koordinasi antara aparatur pemerintah dengan pihak swasta, pengaturan dan promosi umum ke luar negeri. Tidak dapat dipungkiri bahwa hampir diseluruh daerah Indonesia terdapat potensi pariwisata, maka yang perlu diperhatikan adalah sarana transportasi, keadaan infrasruktur dan sarana-sarana pariwisata.

Dari segi ekonomi, pariwisata dimungkinkan dapat menciptakan lapangan pekerjaan didaerah terpencil. Dibanding dengan pariwisata tradisional, dewasa ini pariwisata sangat membutuhkan investasi yang relatif lebih besar untuk pembangunan sarana dan prasarananya. Untuk itu perlu dilakukan evaluasi yang teliti terhadap kegiatan pariwisata alam tersebut. Banyak daerah di Indonesia saat ini yang mampu berkembang perekonomiannya melalui sektor pariwisata. Pada sisi ini, peran pemerintah sangatlah penting dimana dengan berkembangnya pariwisata secara otomatis menarik tenaga-tenaga kerja dan mengurangi pengangguran. Selain itu pemerintah hams jell dalam melihat potensi-potensi pariwisata yang ada pada suatu daerah.

Bila dikaitkan dengan pembangunan perekonomian dengan suatu pertumbuhan yang berimbang, pariwisata dapat diharapkan memegang peranan yang menentukan dan juga dapat dijadikan sebagai katalisator dalam mengembangkan pembangunan sektor- sektor lainnya, karena tidak hanya perusahaan-perusahaan yang dapat menyediakan penginapan/hotel, perencanaan perjalanan

wisata, makanan dan minuman,pramuwisata, tetapi pariwisatajuga memerlukan pula beberapa 
prasarana ekonomi seperti terminal,bandara, stasion, pelabuhan, fasilitas olah raga, faslitas telekomunikasi, Bank danmoneychanger

Hasil penelitian tersebut mendeskripsikan adanya pariwisata dapat menimbulkan dampak yang positif dari pembangunan bidanglainnya. Akan tetapi tidak dapat disangkal bahwa pariwisata juga dapat menimbulkandampak negatif bagi kehidupan masyarakat, misalkan peredaran obat-obatan terlarang, masuknya kebudayaan asing yang tidak sesuai dengan kebudayaan bangsa Indonesia seperti seks bebas dan mabuk-mabukan. Bila diperhatikan dari dampak positif yang diperoleh, sektor pariwisata dapat digunakan sebagai katalisator dalam menggerakkan berbagai kegiatan pembangunan, sehingga dapat diharapkan sebagai sumber devisa negara nomor tiga setelah migas dan non migas. Dalam lingkup pembangunan nasional sektor pariwisata memiliki kontribusi berarti dalam Produk Domestik Bruto (PDB) utamanya bila dikaitkan dengan sektor hotel dan re storan.

\section{Dampak Pengembangan Pariwisata bagi Ekonomi}

Perkembangan pariwisata yang sangat pesat dan terkosentrasi dapat menimbulkan berbagai dampak. Secara umum dampak yang ditimbulkan adalah dampak positif dan dampak negatif. Adapun berbagai dampak yang ditimbulkan dari pengembangan pariwisata dapat diuraikan di bawah ini :

a. Dampak Positif

1) Tercitanya berbagai lapangan kerja disektor pariwisata

2) Memberikan penghasilan tambahan bagi masyarakat yang turut serta memberikan pelayanan kepada para wisatawan yang memerlukan jasanya.

3) Pemerintah mendapat penghasilan berupa pajak penghasilan dan pajak perusahaan pariwisata.

4) Terdorongnya pembangunan di daerah berupa perbaikan sarana dan prasarana dilingkungan daerah karena pemerintah mendapat pendapatan yang dapat digunakan untuk sarana dan prasarana yang kurang memadai.

5) Masyarakat menjadi lebih ingin mempelajari budaya serta adat istiadat agar bisa disajikan pada wisatawan dan dapat menjadikan obyek wisata itu menjadi lebih menarik karena atraksi budaya yang disuguhkan lebih variatif.

6) Masyarakat bisa menguasai beberapa bahasa asing agar bisa berkomunikasi dengan wisatawan asing guna menambah pengetahuan dan pengalaman.

7) Berbagai sumber daya yang ada digunakan secara optimal sehingga dapat menumbuhkan rasa untuk mencintai potensi sumber daya kita sendiri.

b. Dampak Negatif

1) Dampak negatif terhadap lingkungan alam yang mencakup gejala alam yang ada di sekitarnya.

2) Dampak negatif terhadap lingkungan binaan yang mencakup perkotaan, sarana dan prasarana, ruang terbuka, dan unsur bentang kota.

3) Dampak negative terhadap lingkungan budaya yang mencakup nilai-nilai, kepercayaan, perilaku, kebiasaan, moral, seni, hukum, dan sejarah masyarakat

E. 


\section{F. SIMPULAN DAN SARAN}

Hasil penelitian menunjukan bahwa pengembangan industri pariwisata di Indonesia pada realitasnya memiliki pcngaruh yang cukup kuat bagi perkembangan wilayah di daerah khususnya di sekitar obyek wisata, sehinggga dapat berposisi sebagai leading industries, yaitu sektor unggulan yang mampu meningkatkan perekonomian masyarakat. Pariwisata dapat menciptakan lapangan pekerjaan sehingga mendongkrak pendapatan masyarakat di daerah wisata tersebut. Pariwisata dapat memegang peranan penting menentukan dan dapat dijadikan scbagai katalisator untuk mengembangkan pembangunan sektor- sektor lainnya. Dampak pengembangan pariwista bagi ekonomi sangat dirasakan oleh masyarakat.

Seperti yangtelah diketahui bahwa sektor pariwisata memiliki peranan penting dalam mengembangkan perekonomian sehingga sektor ini perlu dikembangkan secara maksimal untuk meningkatkan pendapatan masyarakat di kawasan wisata sekitar dengan terciptanya lapangan pekerja an. Selain itu, perlu adanya kerjasama diantara berbagai pihak seperti pemerintah maupun stakeholder lainnya untuk mengembangkan pariwisata ini. Kemudian sektor pariwisata diharapkan juga dapat menggerakan ekonomi rakyat, karena dianggap sektor yang paling siap dari segi fasilitas, sarana danprasarana dibandingkan dengan sektor usaha lainnya.

\section{DAFTAR REFERENSI}

Badan Pusat Statitik, Berita Resmi Statistik: Perkembangan Pariwisata Dan Transportasi Nasional.Desember 2013.No. 12/02/Th. XVII, 3 Februari 2014. Jakarta: BPS.

Marpaung, Happy, 2000. Pengantar Pariwisata. Bandung, Alfabeta Bandung. Pendit, S.2002. Ilmu Pariwisata Sebuah Pengantar Perdan. Jakarta: PradnyaParamita. Pitana. 2002. Pengantar Ilmu Pariwisata. Yogyakarta PT. Andi.

Soekadijo. $\quad$ R. G. $2000 . \quad$ Anatomi Pariwisata, Memahami Pariwisata Sebagai Sistematic Linkage. Jakarta: Gramedia Pustaka Utama.

Soemardjan, Selo.1980, Kemiskinan Struktural, Suatu Bunga rainpai. Jakarta. Yayasan Ilmu-ilmu social.

Spillane, Jam es,J.S.J.1989. Pariwisata Indonesia, Siasat Ekonomi dan Rekayasa Kebudayaan. Yogyakarta, Kanisius.

Wahab, Salah. 1989. Pemasaran Pariwisata. Jakarta: Pradnya Paramita.

Yoeti, Oka. 1996. Pengantar Ilmu Pariwisata. Jakarta: Angkasa. 